Ál-fâhim: Jurnal Manajemen Pendidikan Islam

Volume 3 No. 2. March-September 2021

ISSN: 2656-226X; E-ISSN: 2656-6036

DOI: $10.0118 /$ alfahim.v3i2.158

\title{
Peran Pendidik dan Lembaga Pendidikan dalam Membentuk Kesalehan Individu (Studi Perspektif Normatif)
}

Mulyani, Melisa, Risman Bustamam

SMAN 1 Koto Salak, SMAN Unggul Dharmasraya, Institut Agama Islam Negeri Batusangkar, Sumatera Barat mulyanisosiologi@gmail.com, meliummianna@gmail.com, risman77bust@gmail.com

\begin{abstract}
This study aims to find out the role of educational institutions and educators in shaping individual mistakes. This research uses a qualitative approach based on literature study. The results of this study indicate that educators in the sense of being nurtured and imitated have a very large role in shaping the morality of students to become a pious generation. Educators and students as a unit that has an attachment to each other. Islamic educational institutions need to manage education including educators and students. Educators and students are human resources who have an important role in shaping piety.
\end{abstract}

Keywords: Educators, Students, Human Resources

Abstrak: Penelitian ini bertujuan untuk mencari peran Lembaga Pendidikan dan pendidik dalam membentuk kesalahen individu. Penelitian ini menggunakan pendekatan kualitatif berbasis studi pustaka. Hasil penelitian ini menyatakan bahwa Pendidik dalam artian sosok yang digugu dan ditiru memiliki peran yang sangat besar dalam membentuk akhlakul karimah peserta didik menjadi generasi yang salih. Pendidik dan peserta didik sebagai satu kesatuan yang memiliki keterikatan satu sama lain. Lembaga pendidikan Islam perlu mengelola pendidikan termasuk pendidik dan peserta diidk. Pendidik dan peserta didik merupakan sumber daya manusia yang memiliki peran penting dalam membentuk kesalehan.

Kata Kunci: Pendidik, Peserta didik, Sumber Daya Manusia

\section{Pendahuluan}

Pendidikan merupakan sebuah upaya yang dilakukan secara sadar, terencana, dan tertata untuk membentuk generasi penerus sebagai sumber daya manusia yang memiliki kecakapan dan kemampuan dari segi pengetahuan, sikap dan keterampilan. Ini telah tertuang dalam Undangundang nomor 20 tahun 2003 mengenai sistem pendidikan nasional yang menjelaskan tentang pendidikan,sebagai sebuah usaha sadar dan terencana untuk mewujudkan situasi dan suasana kegiatan belajar dan pembelajaran

|Submitted: July 5, 2021 | Accepted: Sept 30, 2021 | Published: Sept 30, 2021 
pada peserta didik untuk menjadi lebih aktif dalam mengembangkan potensi yang dimilikinya untuk dapat memimiliki potensi spriritual, mampu mengendalikan diri, cerdas, berakhlak mulia serta memiliki keahlian dan keterampilan yang nanti berguna serta diperlukan baik bagi dirinya sendiri, masyarakat sekitar, bangsa dan Negara. ${ }^{1}$

Butuh upaya yang harus dilakukan oleh lembaga pendidikan guna mencapai hasil yang hendak dicapai. Untuk mencapainya lembaga pendidikan membutuhkan peranan pendidik dan juga keterlibatan peserta didik dalam setiap prosesnya. Pendidik sering dikenal masyarakat sebagai guru yang bekerja di sekolah. Sebagai guru pendidik bertugas mentransfer ilmu dan pengetahuan kepada peserta didik, membimbing dan membina peserta didik. Tidak hanya itu saja, guru juga bertanggung jawab dalam menanamkan nilai-nilai dan karakter agar lahir peserta didik sebagai sumber daya manusia yang handal, cerdas spiritual, sosial dan emosial, memiliki karakter yang bagus. Tugas yang diemban seorang pendidik bukanlah tugas yang ringan, dimana tanggung jawab tersebut dipikul tidak hanya di dunia saja melainkan juga sampai akhirat.

Pendidik dalam konsep islami, pendidik bukan hanya guru di sekolah. Di dalam Al Quran dijelaskan bahwa pendidik adalah Allah SWT sebagai pendidik yang utama, Rasulullah SAW, orang tua dan guru sebagai pendidik di sekolah. Namun demikian pendidikan juga dapat diperoleh dari alam sekitar dalam pepatah Minangkabau Sumatera Barat "Alam Takambang Jadi Guru", memiliki makna, bahwa belajar dapat diperoleh dari alam sekitar. Sementara itu peserta didik merupakan orang atau manusia dari berbagai tingkat usia tanpa batas yang terus menerus belajar dan memperoleh pembelajaran. Dalam lingkungan pendidikan, peserta didik adalah anak-anak yang usianya telah ditetapkan sesuai dengan jenjang pendidikan yang ditempuh. Setiap jenjang pendidikan memiliki tingkatan usia yang berbeda-beda.

Pendidik dan peserta didik merupakan komponen pendidikan yang memiliki keterkaitan dan tidak bisa dipisahkan. Pendidik tanpa peserta didik tidak akan memiliki arti, begitupun peserta didik tanpa pendidik juga tidak dapat memperoleh dan menerima proses pembelajaran. Lembaga pendidikan menjadi wadah bagi pendidik dan pserta didik dalam melakukan proses belajar dan pembelajaran. Meskipun kegiatan pendidikan tidak harus terikat oleh lembaga pendidikan. Pendidikan dapat dilakukan dimanapun dan kapanpun, tanpa terikat ruang dan waktu. Pendidikan berlaku sepanjang hayat manusia. Pendidik dan peserta didik

1 Undang-Undang RI No. 20 Tahun 2003, Tentang Sistem Pendidikan Nasional, Jakarta: Departemen Pendidikan Nasional, 2003, p. 3 
sebagai sumber daya manusia yang saling membutuhkan satu sama lain dalam setiap proses pembelajaran.

Selaras dengan penelitian Suarga, ia menyatakan bahwa pendidik merupakan satu sistem yang sangat penting dalam Lembaga Pendidikan. Menurutnya, pendidik diharapkan dapat memajukan dunia pendidikan, oleh sebab itu pendidik memiliki tugas-tugas kependidikan yang amat berat, walaupun mereka sering mendapatkan perlakuan yang kurang adil. ${ }^{2}$

Peran pendidik dalam membentuk kesalehan peserta didik pada masa sebelumnya secara umum adalah bertanggung jawab untuk mendidik, dan membentuk kesalehan peserta didik yang dapat dilakukan langsung oleh pendidik kepada peserta didik. Pada kondisi sekarang ditengah pandemi covid-19, dimana intensitas pertemuan antara pendidik dengan peserta didik sangat terbatas, namun perannya tetap harus dilakukan dalam membentuk kesalehan peserta didik. Dengan menggunakan media teknologi pendidik harus mampu dengan bijak mengajarkan dan membiasakan nilai-nilai kesalehan kepada peserta didik dalam kondisi new normal dan pertemuan terbatas. Ini menjadi satu tantangan yang membutuhkan loyalitas dan tanggung jawab besar buat pendidik agar tetap mampu membentuk nilai-nilai kesalehan pada peserta didik.

Berdasarkan analisis diatas, maka dapat dikatakan bahwa peranan pendidik dan Lembaga pendidikan dalam membentuk karakter peserta didik sebagai sumber daya manusia sangat penting, Maka dari itu, penulis tertarik untuk memaparkan konsep pendidik dan peserta didik sebagai sumber daya manusia. Dengan rumusan masalah, bagaimana peran pendidik dalam membentuk kesalehan peserta didik, selain itu akan dijelaskan juga bagaiamana peran Lembaga Pendidikan sebagai wadah Pendidikan.

\section{Metode Penelitian}

Penelitian ini menggunakan jenis penelitian studi kepustakaan. Penelitian dilakukan dengan cara menghimpun sumber-sumber kepustakaan. Dalam penelitian kepustakaan peneliti mengumpulkan berbagai informasi serta data dari berbagai sumber yang terdapat diperpustakaan seperti buku, jurnal, artikel yang diterbitkan media massa, serta berbagai jurnal elektronik yang erat kaitannya dengan permasalahan yang dibahas ${ }^{3}$. Objek kajian penelitian kepustakaan yaitu berbagai sumber

2 Suarga, Tugas dan Fungsi Manajemen Pendidik dan Tenaga Kependidikan, Jurnal Idaarah 3, no 1 (2019), p. 164

3 Milya Sari dan Asmendri, Penelitian Kepustakaan (Library Research), Penelitian Pendidikan IPA, (2020). 
literasi yang dirujuk dari jurnal-jurnal penelitian serta buku sumber. Sumber primer dari penelitian ini adalah buku referensi yang relevan, Ayat Al Quran dan jurnal-jurnal penelitian terdahulu yang memuat kajian yang akan dibahas, sementara sumber sekundernya adalah jurnal penelitian yang juga memiliki keterkaitan dengan kajian. Teknik analisa data yang digunakan adalah deduktif. Dimana pemikiran yang bertolak pada faktafakta umum selanjutnya akan ditarik kesimpulan yang lebih bersifat khusus. Teknik kualitatif dilakukan melalui kegiatan observasi dan telaah dokumen. Telaah dokumen dilakukan dengan cara menghimpun berbagai sumber-sumber tertulis seperti buku, jurnal baik cetak maupun elektronik, surat kabar dan lain-lain. ${ }^{4}$ Sumber yang dicari dan dibutuhkan adalah sumber yang membahas tentang kajian manajemen pendidik dan peserta didik, meliputi konsep pendidik menurut Al Quran.

\section{Hasil Penelitian dan Pembahasan}

\section{A. Definisi Pendidik}

Definisi pendidik dilihat dari asal katanya yaitu didik yang memiliki makna merawat, memelihara, dan memeberi latihan supaya manusia baik individu atau kelompok memiliki ilmu pengetahuan yang benar-benar diharapkan. Selain ilmu pengetahuan juga berkaitan dengan sopan santun, akal budi, akhlak dan perilaku lainnya. Kemudian kalimat didik ditambah awalan pe- sehingga menjadi kata pendidik yang memiliki arti sebagai orang yang mendidik. Menurut Kamus Bahasa Indonesia, pendidik merupakan orang yang mendidik. ${ }^{5}$ Setiap orang pada dasarnya adalah pendidik 6

Pendidik dalam konsep Al Quran meliputi Allah SWT sebagai pendidik utama, rasulullah SAW yang menjadi panutan dan suri tauladan bagi setiap pendidik yaitu guru dan orang tua. Selain itu juga manusia dapat mendapatkan ilmu dan pengetahuan serta pemdelajaran dari alam sekitar. Dalam pepatah minang diistilahkan "alam takambang jadi guru", dalam artian bahwa alam juga sebagai pendidik dalam kehidupan.

Pendidik adalah orang yang memiliki tanggung jawab terhadap tumbuh kembangnya anak didik. Pendidik berupaya untuk mengembangkan segala potensi yang dimiliki oleh anak didik meliputi tiga ranah yaitu pengetahuan, sikap dan keterampilan. ${ }^{7}$ Pendidik juga merupakan orang yang memiliki tanggung jawab dalam meendidik anak

4 Arikunto Suharsimi, Prosedur Penelitian Suatu Pendekatan Praktik, 2006.

5 W.J.S. Poerwadarminta, Kamus Umum Bahasa Indonesia, Jakarta: Balai Pustaka, 1991, p. 250.

${ }^{6}$ Ade wahidin, Filosofi Manusia Sebagai Pendidik, 2015.

7 Ahmad Tafsir, Ilmu Pendidikan dalam Perspektif Islam, Bandung: Remaja Rosdakarya, 2002, p. 74-75. 
didiknya dna memperhatikan perkembangannya secara jasmaniah dan ruhaniah. ${ }^{8}$ Pendapat lainnya pendidk sebagai orang yang memberikan ilmu dan pengetahuannya, pengalaman, keahlian dalam lingkungan sekitar anak didik yaitu keluarga, masyarakat maupun sekolah. ${ }^{9}$ Selain itu dalam islam pendidik adalah siapapun yang memiliki tanggung jawab terhadap perkembangan anak didik. Dimana tanggung jawab pertama itu berada pada pundak orang tua yaitu ayah dan ibu. ${ }^{10}$ Pendidik dalam islam dikenal dengan murabi, mu'allim, muadib, mudaris, muzakki dan yang paling familiar yaitu ustadz/ ustadzah. ${ }^{11}$

\section{B. Pendidik dan Peserta Didik dalam Al quran}

Pendidik memiliki makna yang sangat luas. Dalam pendidikan islam pendidik dijabarkan menjadi emapt yaitu Allah SWT sebagai pendidik utama, rasulullah SAW, orang tua dan juga guru pendidik di sekolah. Namun selain itu juga alam dapat menjadi sumber pendidikan bagi manusia di dunia. Dalam pepatah minang dikenal dengan istilah "alam takambang jadi guru". Berikut penjabaran mengenai pendidik:

1. Allah SWT sebagai pendidik utama.

Dalam AlQuran surat Al Baqarah ayat 31-32

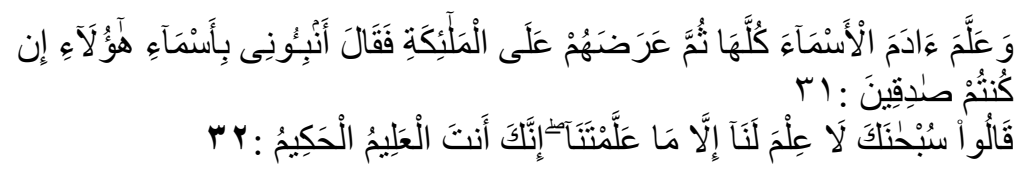

Artinya: "Dan Dia ajarkan kepada Adam nama-nama (benda) semuanya, kemudian Dia perlihatkan kepada para Malaikat, seraya berfirman, "Sebutkan kepada-Ku nama semua benda ini, jika kamu yang benar! Mereka menjawab,'Mahasuci Engkau, tidak ada yang kami ketahui selain apa yang telah Engkau ajarkan kepada kami. Sungguh, Engkaulah Yang Maha Mengetahui, Mahabijaksana".

Secara tersurat dalam ayat tersebut bahwa Allah SWT telah mengajarkan kepada nabi Adam AS mengenai nama benda yang ada. Ini mengandung makna bahwa manusia sebagai makhluk paling mulia

8 Ramayulis dan Syamsul Nizar. Filsafat Pendidikan Islam: Telaah Sistem Pendidikan dan Pemikiran Para Tokohnya, Jakarta: Kalam Mulia, 2010, p. 139.

${ }^{9}$ Maragustam, Filsafat Pendidikan Islam. Yogyakarta: Sunan Kalijaga, 2010, p. 169.

${ }^{10}$ Ahmad Tafsir, Ilmu Pendidikan dalam Perspektif Islam, Bandung: Remaja Rosdakarya, 2002.

11 Heru Juabdin Sada, Pendidik dalam Perspektif Al Quran, 2015. 
dianugerahi potensi yang lebih baik dari makhluk lainnya untuk mengenal, memahami nama, fungsi mupun karakteristik benda yang terdapat disekitarnya. Melalui surat ini Allah SWT telah menunjukkan suatu keistimewaan yang dikaruniakan kepada nabi Adam as dimana karunia ini tidak pernah diberikan pada makhluk lainnya. Karunia ini berupa ilmu pengetahuan dan juga akal pikiran yang dapat digunakan untuk mempelajari segala sesuatu denga sebaik-baiknya yang diturunkan pada umat manusia.

Sementara itu pada ayat 32, mengandung makna bahwa dengan cara tulus malaikat menyucikan Allah dan menjawab bahwasanya tidak ada pengetahuan bagi kami kecuali apa yang telah engkau ajarkan pada kami. Sesungguhnya Engkaulah yang Maha Mengetahui lagi Maha Bijaksana. Maksud mereka, apa yang Engkau tanyakan itu tidak pernah Engkau ajarkan kepada kami. Engkau tidak ajarkan kepada kami bukan karena Engkau tidak tahu, tetapi karena ada hikmah dibalik itu.

Allah SWT sebagai pendidik utama dan yang paling tahu dengan hakikat manusia terdapat dalam QS Ar Rahman ayat 2-4 yan artinya: 2). yang telah mengajarkan Al Quran. 3). Dia menciptakan manusia. 4). mengajarnya pandai berbicara. Allah SWT selaku sang maha penncipta menciptakan manusia untuk bisa mempelajari segala ilmu pengetahuan. Allah mengajarkan manusia pandaai berbicara sehingga nanti mampu berdakwah menyampaikan ilmu pengetahuan kepada yang lainnya. Manusia dapat menyampaikan dengan kata-kata, perbuatan, ucapan, tulisan maupun bahasa isyarat lain yang dpat dipahami sebagai alat komunikasi

Ayat lainnya yang menyatakan Allah SWT sebagai pendidik dapat dilihat pada QS Al Alaq ayat 1-5 Artinya: 1) Bacalah dengan (menyebut) nama Tuhanmu yang Menciptakan, 2) Dia telah menciptakan manusia dari segumpaldarah. 3) Bacalah, dan Tuhanmulah yang Mahapemurah, 4) yang mengajar (manusia) dengan perantarankalam, 5) Dia mengajar kepada manusia apa yang tidakdiketahuinya.

Ayat-ayat diatas menjelaskan bahwa Allah SWT adalah guru. Allah sebagai pendidik utama yang menyampaikan ilmu penegtahuan melalui rasullullah SAW sebagaimana dalam surat Al Alaq. Allah SWT adalah pendidik utama yang mengetahui apapupun yang menjadi kebutuhan umat manusia sebagai makhluk yang dididik-Nya. Tidak sebatas itu saja, Allah juga memperhatikan segala apa yang ada di langit dan di bumi. Dia sebagai pencipta memperhatikan semua isi alam semesta.

2. Nabi/Rasul sebagai pendidik

Rasulullah SAW dikenal dengan akhlaknya yang mulia. Tidak hanya itu, sosoknya menjadi panutan yang dipatuhi dan sukses mendidik generasi 
yang islami. Rasulullah mengajarkan ketauhidan, etika, keteladanan. Memiliki kepribadian yang sangat mulia dan pantas untuk ditiru oleh siapa saja.

Dalam ayat Al Quran surat Al Jumuah/62:2 : Artinya : “Dialah yang mengutus seorang Rasul kepada kaum yang buta huruf dari kalangan mereka sendiri, yang membacakan kepada mereka ayat-ayat-Nya, menyucikan (jiwa) mereka dan mengajarkan kepada mereka Kitab dan Hikmah (Sunnah), meskipun sebelumnya, mereka benar-benar dalam kesesatan yang nyata."

Nabi Muhammad SAW merupakan utusan Allah untuk memberantas buta huruf. Melalui ayat suci Al Qur'an yang didalamnya mengandung petunjuk dan bimbingan untuk mendapatkan kebaikan akhirat, menjauhkan dari hal yang menyesatkan dan bersifat jahiliah, kemusrikan serta untuk bertauhid mengesakan Allah dan tidak tunduk pada pemimpin yang menyesatkan, dan tidak percaya pada hal-hal yang menyesatkan seperti berhala, pohon dan lainnya. Selain itu juga mengajarkan pada al kitab yang berisi syariat agama dan hokum serta hikmah yang terkandung di dalamnya.

Rasulullah SAW merupakan model bagi setiap umat manusia dalam mendidik. Semua teknik, metode dan cara yang digunakan Rasulullah SAW dapat dipahami dengan mudah. Setiap peserta didik akan mudah memahami ilmu dan nilai-nilai yang diajarkan Rasulullah SAW dalam ranah pengetahuan, sikap dan keterampilan ${ }^{12}$.Rasulullah merupakan teladan yang memiliki karakteristik dan akhlak mulia yang hebat sebagai seorang guru atau pendidik bagi umat manusia ${ }^{13}$. Rasulullah SAW juga seorang pendidik professional, tidak hanya menguasai materi tetapi juga menguasai teknik dan berakhlak mulia ${ }^{14}$

Nabi Muhammad adalah sebagai seorang pendidik yang professional, yaitu seorang pendidik yang disamping harus menguasai materi pengajaran, juga harus menguasai teknik mengajar yang efisien dan efektif serta berakhlak mulia

3. Guru sebagai pendidik

Dalam Al Quran surat Al Kahfi ayat 65-66 yang berbuny sebagai berikut:

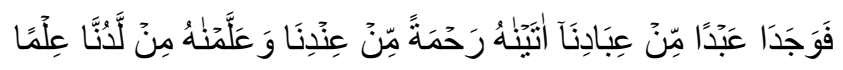

12 Ratna Kasni Yuniedel dan sasmi Nelwati, meneladani Rasulullah SAW Sebagai Pendidik Yang Menmudahkan, 2019

${ }^{13}$ Junaidi Arsyad, Karakteristik Rasulullah sebagai Pendidik, Perspektif Sirah nabawiyah, 2015

14 Nazifah Anas, Rasulullah sebagai pendidik professional, 2015 


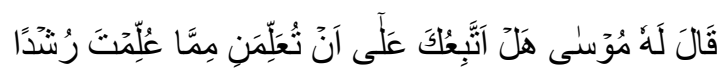

Artinya: Lalu mereka berdua bertemu dengan seorang hamba di antara hamba-hamba Kami, yang telah Kami berikan rahmat kepadanya dari sisi Kami, dan yang telah Kami ajarkan ilmu kepadanya dari sisi Kami. Musa berkata kepadanya, "Bolehkah aku mengikutimu agar engkau mengajarkan kepadaku (ilmu yang benar) yang telah diajarkan kepadamu (untuk menjadi) petunjuk?"

Ayat diatas memiliki makna berkaitan dengan pendidikan untuk mengajarkan ilmu yang benar yang sebelumnya telah diajarkan kepada nabi untuk dijadikan sebagai petunjuk. Guru yang dikenal sebagai pendidik di sekolah emmiliki tugas dan tanggung jawab yang berat untuk menyampaikan ilmu dan kebenaran kepada setiap peserta didik yang menjadi tanggung jawabnya di sekolah. Guru bukan sekedar orang yang berdiri di depan kelas tetapi juga bagian dari masyarakat yang harus aktif dan kreatif. Guru memiliki tanggung jawab mengarahkan, membimbing dan mendidik generasi atau peserta didik menuju proses pendewasaan berpikir baik dari ranah pengetahuan, sikap maupun keterampilannya. Semua ranah diasah di sekolah melalui bimbingan dan binaan guru. Dalam pengertian ini tugas guru sangat berat, yang harus dipikul oleh seorang pendidik khususnya guru. Tugas tersebut, selain memberikan di depan kelas, juga membantu mendewasakan anak didik. ${ }^{15}$

Siapapun yang telah terjun dan berkecimpung dalam dunia pendidikan sudah semestinya harus berkepribadian seorang pendidik. Guru sebagai pendidik bukan hanya sebagai penyaji materi dalam kelas, guru juga merupakan fasilitator, motivator,pembimbing yang harus lebih banyak memberi kesempatan kepada peserta didik untuk berkembang dengan sebaik-baiknya. ${ }^{16}$

\section{Orangtua sebagai pendidik}

Ayah dan Ibu sebagai orang tua merupakan manusia yang pertama dikenal oleh individu pada lingkungan keluarga. Orang tua dengan kasih dan sayangnya menjadi pendidik bagi anak-anaknya. Hal ini diperkuat dengan ayat Al Quran yang tercantum dalam surat Al Isra ayat 24

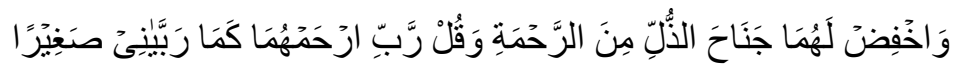

15 Abuddin Nata, Filsafat Pendidikan Islam, (Jakarta: Logos Wacana Ilmu, 1997.

${ }^{16}$ M. Yusuf Seknun, Kedudukan guru sebagai pendidik, 2012. 
Artinya: "Dan rendahkanlah dirimu terhadap keduanya dengan penuh kasih sayang dan ucapkanlah, "Wahai Tuhanku! Sayangilah keduanya sebagaimana mereka berdua telah mendidik aku pada waktu kecil."

Allah memerintahkan kepada semua umat manusia untuk bersikap rendah hati dan memiliki rasa kasih dan saying kepada orang tua yaitu bapak dan ibu. Sikap tersebut dapat dilakukan dengan mentaati apa yang diperintahkan oleh orang tua menyayangi orang tua, mengkuti apa yang disampaikan orang tua sesuai dengan syariat agama. Pada ayat terakhir, Allah SWT menyatakan melalui perintah-Nya kepada semua kaum muslimin untuk mendoakan kedua orang tua yaitu ibu dan bapak. Mengharapkan limpahan kasih dan saying dari Allah kepada mereka yang telah menyayangi dan mengasihi anak-anaknya pada waktu kecil. Orang tua sebagai pembimbing dalam lingkungan keluarga disebabkan karena secara alami anak anak pada masa awal kehidupannya berada ditengahtengah ayah dan ibunya.

Orang tua baik dari ayah maupun ibu merupakan pendidik dalam lingkungan yang pertama kali dikenal oleh anak yaitu keluarga. Dalam surat Al Luqman ayat 13 dinyatatakan, artinya: "Dan (ingatlah) ketika Lukman berkata kepada anaknya, ketika dia memberi pelajaran kepadanya, "Wahai anakku! Janganlah engkau mempersekutukan Allah, sesungguhnya mempersekutukan (Allah) adalah benar-benar kezhaliman yang besar." Luqman sebagai orang tua menyampaikan kepada anaknya untuk tidak mempersekutukan Allah SWT. Orang tua hendaknya memahami ini dan menyampaikan kepada anaknya sebagaimana yang dilakukan Luqman kepada putranya. ${ }^{17}$

Allah telah memerintahkan kepada semua umat manusia agar berbuat baik kepada bapak ibunya. Orang tua merupakan pendidik yang pertama dikenal anak setelah lahir ke dunia. Maka anak wajib menghormati, menghargai dan menyayangi orang tua serta berbuat baik sesuai dengan yang diperinthkan orang tua. Berbuat baik kepada orang tua merupakan amal yang tinggi nilainya di sisi Allah SWT.

5. Alam sebagai guru

Falsafah minang "alam takambang jadi guru", memiliki makna bahwa belajar bisa dari alam. Alam dapat menjadi sumber belajar bagi umat manusia dan makhluk hidup lainnya. Sebagaimana yang termaktub dalam beberapa surat Al quran. Pada surat Al Maidah ayat 31 yang berbunyi:

${ }^{17}$ Maisyaroh, Hakikat Pendidik dalam Perspektif Falsafah Pendidikan Islami, p. 2019 


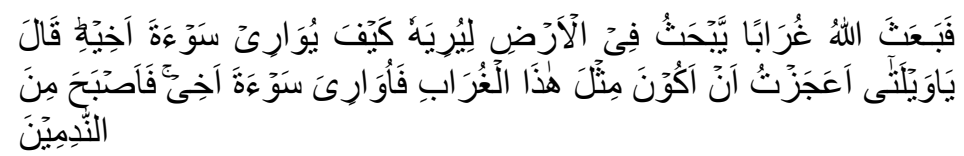

Artinya: "Kemudian Allah mengutus seekor burung gagak menggali tanah untuk diperlihatkan kepadanya (Qabil). Bagaimana dia seharusnya menguburkan mayat saudaranya. Qabil berkata, "Oh, celaka aku! Mengapa aku tidak mampu berbuat seperti burung gagak ini, sehingga aku dapat menguburkan mayat saudaraku ini?" Maka jadilah dia termasuk orang yang menyesal."

Surat Al Nur ayat 41:

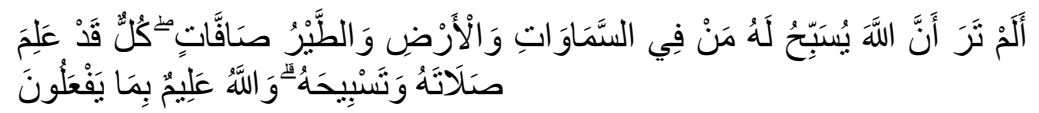

Artinya: "Tidaklah kamu tahu bahwasanya Allah: kepada-Nya bertasbih apa yang di langit dan di bumi dan (juga) burung dengan mengembangkan sayapnya. Masing-masing telah mengetahui (cara) sembahyang dan tasbihnya, dan Allah Maha Mengetahui apa yang mereka kerjakan."

Dari kisah tersebut, manusia dapat belajar dari alam. Ayat diatas menggambarkan bahwa burung gagak secara tidak langsung mengajarkan bagaimana cara menguburkan mayat. Dan pada ayat kedua bahwa manusia sepatutnya dan seharusnya bertasbih kepada Allah SWT. Burung dengan caranya bertasbih kepada Allah SWT. Manusia tentunya mengetahui cara beribadah kepada tuhannya. Ini menandakan bahwa alam dapat menjadi sumber belajar bagi manusia. Berdasarkan beberapa uraian ayat Al Quran diatas, bahwa alam juga dapat menjadi tempat manusia belajar. Alam dapat menjadi guru bagi manusia didunia ini.

\section{Hadist Tentang Lembaga Pendidikan dan Peserta Didik}

1. Hadist Tentang Manajemen Pendidik

Hadits tentang pendidik harus mengutamakan prinsip memotivasi dan memudahkan, "Dari Abu Musa beliau berkata: " Rasulullah SAW apabila mengutus salah satu orang sahabatnya untuk mengerjakan sebagian perintahnya selalu berpesan " Sampaikan berita gembira oleh kalian dan janganlah kalian menimbulkan rasa antipati, berlaku mudahlah kalian dan janganlah kalian mempersulit ".

Nilai tarbawi dari hadist diatas yaitu sebaiknya mengajarkan sesuatu 
yang mudah dipahami dan diterima oleh peserta didik, tidak mengajarkan yang sulit dan menyusahkan, mengajar dengan luwes dan diselingi humor, menyesuaikan dengan situasi dan kondisi peserta didik, memberikan kasih saying dengan perlakuan yang adil sehingga mereka dekat dengan guru, ketika guru merasa kesulitaan dengan apa yang disampaikan kepada peserta didik maka lakukan diskusi.

Rasulullah SAW adalah pendidik yang langsung ditunjuk oleh Allah SWT dan sebagai teladan bagi semua ummat. Selalin itu rasulullah SAW adalah rahmat bagi seluruh alam dan segala isinya. Dalam haditsnya yang diriwayatkan oleh Ahmad yang artinya: "Dari Abu Hurairah ra., Rasulullah Saw. bersabda, "Sesungguhnya saya diutus (kepada manusia hanyalah) untuk menyempurnakan akhlak.". (H.R. Ahmad).

Rasulullah SAW sebagai pedidik bagi semua umat manusia di dunia menyampaikan dan mengajarkan agama islam serta ketauhidan kepada Allah yang maha esa. Rasulullah merupakan sosok yang memiliki kepribadian yang luhur, akhlak yang mulia dan sebagai sosok yang patut ditauladani oleh seluruh umat manusia di dunia. Kepribadian dan akhlaknya tercermin dari setiap perilaku dalam kehidupannya.

\section{Hadits tentang pendidik.}

Pendidik adalah sebuah profesi. Setiap pendidik hendaknya professional dimana harus memiliki keahlian sesuai dengan bidangnya. Sebagaimana dikemukakan oleh "Abu hurairoh berkata, suatu hari Nabi Muhammad SAW berdiskusi dan bercerita dengan kaumnya dalam sebuah majelis lalu datang seorang badui dan bertanya: kapan kehancuran terjadi? Rasulullah masih tetap berbicara kepada kaumnya dan diantara sebagian kaum mendengarkan apa yang ditanyakan badui sehingga mereka tidak senang terhadap Rasulullah atas perkataannya sebagian diantaranya mengganggap bahwa Rasulullah tidak mendengarnya sampai Rasulullah menyelesaikan pembicaraannya. Rasulullah bertanya: “dimana orang yang ingin mengetahui tentang kehancuran?, orang badui itu menjawab: "saya ya rasul", kemudian Rasulullah berkata: terjadinya kehancuran yakni ketika sebuah amanah disia-siakan". Lalu orang badui itu kembali bertanya: "bagaimanakah amanah itu disia-siakan?", Rasulullah menjawab: "ketika sebuah urusan diserahkan kepada orang yang bukan ahlinya maka tunggulah kehancurannya".

Nilai tarbawi dalam hadits tersebut adalah professional. Pekerjaan harus dikerjakan secara professional dan dilakukan oleh orang sesuai dengan keahliannya. Maka jika tidak akan terjadilah suatu kehancuran. Seorang pendiik adalah profesi, maka harus konsekuen dengan semua tanggung jawab dari profesi yang diembannya. 


\section{Hadist Tentang Peserta Didik}

Peserta Didik adalah seseorang yang berada dalam tahap pertumbuhan dan perkembangan baik fisik maupun mental. Dalam lingkungan sekolah peserta didik dibatasi dari segi usia, meskipun sebenarnya semua manusia adalah peserta diidk dan juga pendidik. Nabi Muhammad SAW, begitu memperhatikan perkembangan ilmu pengetahuan dan teknologi. Dalam hadits yang berbicara tentang mencari ilmu. Perhatian yang sedemikian tinggi adalah karena nabi juga sebagai pendidik, Rasulullah lebih memprioritaskan majelis ilmu untuk pelajar. Di antara hadis yang membicarakan tentang peserta didik adalah sebagai berikut ${ }^{18}$ :

a) Hadis yang diriwayatkan oleh Bukhari, bersumber dari $\mathrm{Mu}^{\prime}$ awiyah Khatiban, dalam rangka menumbuh kembangkan peserta didik yang memiliki kualitas menurut kajian hadis, dapat dikatakan bahwa Rasulullah menyampaikan melalui penjelasannya jika ilmu dapat diperoleh melalui proses belajar. artinya, melalui kerja keras dan cerdas seseorang dapat memperoleh ilmu. Tidak hanya mengejar semata. Orang yang ulet, rajin dan tekun dalam belajar akan mendapatkan ridho dari Allah SWT dengan pemahaman agama di masa depan yang kelak akan dapat membawa pada kemuliaan, kebaikan dan kebahagiaan.

b) Hadis yang diriwayatkan oleh Bukhari, bersumber dari Abdullah ibn Mas'ud:"Menceritakan kepada kami Humaid, ia berkata, menceritakan kepada kami Sufyan, ia berkata, menceritakan kepadaku Isma'il ibn Abu Khalid atas selain yang kami ceritakan oleh nya al-Zuhriy, ia berkata, "aku mendengar Ibn Qais ibn Abu Hazim, ia berkata, aku mendengar'Abdullah ibnMas'ud berkata, Nabi saw, bersabda, "tidak boleh iri hati kecuali dua hal, yaitu seorang laki-laki yang diberi harta oleh Allah lalu harta itu dikuasakan penggunaan nya dalam kebenaran, dan seorang laki-laki diberi hikmah oleh Allah dimana ia memutuskan perkara dan mengajar dengannya" (H.R.Bukhari).

Hadits-hadits di atas menunjukkan bahwa sebagai pelajar, mereka harus mencari ilmu agama dan ilmu pengetahuan dengan sungguhsungguh atau tekun. Peserta didik dituntut untuk menjadi ilmuwan atau orang pintar sebelum menikah atau menjadi pemimpin. Kecuali dua aspek ilmu dan kebaikan, siswa tidak boleh iri terhadap orang lain. Siswa dituntut untuk berkompetisi dalam studinya atau belajar dengan cara yang baik. Sebagai siswa, ketika mereka memperoleh pengetahuan, mereka harus

${ }^{18}$ Amiruddin Siahaan dan Nur Hidayah, 2014, Hadis-Hadis tentang Peserta Didik, Nadwa, Jurnal Pendidikan Islam 8, no 1, (2014), p. 4-7 
memanfaatkan pengetahuan ini dengan baik dan menyebarkannya kepada orang lain.

Hadis yang diriwayatkan oleh Bukhari,bersumber dari Abu Hurairah ra:"Menceritakan kepada kami Ahmad ibn Abu Bakar al-Siddiq AbuMus'ab,ia berkata, menceritakan kepada kami Muhammad ibn Ibra- him ibn Dinar, dari Ibn Abi i'bu, dari Sa'id al-Maq buriy, dari AbuHurairah, iaberkata, aku berkata kepada Rasulullah saw., "wahai Rasulullah, sesungguhnya aku banyak mendengar hadis dari engkau, lalu aku lupa?" Rasulullahsaw, bersabda, "hilangkan perkara yang burukmu, "lalu aku menghilangkan nya... lalu Rasulullahsaw., ber- sabda, "hafalkanlah"lalu aku menhapalkan nya," setelah itu aku tidak melupakan suatu hadis pun setelah itu," (HR.Bukhari). (jika sumber kutipan lebih dari 4 baris maka di buatkan paragraf khusus).

Hadits tersebut mengandung makna dan memberikan suatu pemahaman pada peserta didik agar ilmu yang telah diperoleh dapat terpelihara dengan baik. Bentuk upaya memelihara ilmu yang diperoleh dengan cara mengulang kembali pelajaran yang diberikan guru yang telah berlalu. Peserta diidk hendaknya merasa butuh akan ilmu, sehingga mudah baginya untuk menerima dan memahami. Selain itu juga menuntut ilmu adalah untuk memperoleh keridhaan Allah SWT dan sebagai sarana untuk meraih surga.

Dua hal yang dapat dipahami dari hadits di atas, Pertama: Setiap orang sejak lahir memiliki potensi, baik potensi agama maupun potensi untuk menjadi orang baik, dan potensi untuk menjadi orang jahat dan potensi lainnya. Kedua: Potensi ini dapat dipengaruhi oleh lingkungan, terutama orang tua, karena merekalah yang pertama memainkan peran penting dalam membuat anak-anaknya menjadi orang Yahudi, Kristen, atau Majusi.Konsep hadis ini sejalan dengan teori konvergensi perkembangan siswa, yang meyakini bahwa setiap anak yang lahir dipengaruhi oleh faktor keturunan dan lingkungan selama perkembangannya. Dengan kata lain, setiap anak yang lahir akan dipengaruhi oleh keturunannya, misalnya anak dari keluarga yang baik tentu akan menjadi anak yang baik dan juga akan terpengaruh oleh lingkungan.

Pendidik atau guru Islam adalah orang yang bertanggung jawab atas perkembangan peserta didik dan berupaya mengembangkan seluruh potensi peserta didik, meliputi potensi emosi (rasa), kognisi (kreatif) dan gerak mental (niat). Pendidik juga berarti bahwa orang dewasa bertanggung jawab untuk membantu perkembangan fisik dan mental siswa untuk mencapai tingkat kedewasaan, mampu mandiri dan mencapai tingkat kedewasaan, mampu secara mandiri menjalankan tugasnya sebagai hamba dan khalifah Allah dan mampu melaksanakan tugas sebagai makhluk sosial 
dan sebagai makhluk individu yang mandiri ${ }^{19}$.

Pendidik pertama adalah orang tua itu sendiri. Mereka semua bertanggung jawab atas perkembangan dan kemajuan anak-anaknya sendiri, karena berhasil tidaknya anak-anaknya sangat bergantung pada pengasuhan, perhatian dan pendidikan. Sebagai pendidik utama bagi anaknya, orang tua tidak selalu memiliki waktu luang untuk mendidik anaknya. Selain kesibukan kerja, jika pendidikan hanya dikelola secara alami, efek dan efisiensi pendidikan tidak akan terlalu baik. Oleh karena itu, anak biasanya diikutsertakan dalam lembaga sekolah. Mengirim siswa ke lembaga sekolah bukan berarti melepaskan tanggung jawab orang tua sebagai pendidik dasar, tetapi orang tua tetap memiliki minat yang besar dalam membesarkan dan mendidik anak kandungnya.

\section{Peran Pendidik Dalam Membentuk Kesalehan Individu}

Pendidik yang lebih dikenal sebagai guru memiliki peran dan tanggung jawab dalam proses mendidik. Dalam perspektif islam pendidik merupakan orang yang bertanggung jawab terhadap semua tumbuh kembang peserta didik baik pengetahuan, sikap, sosial, keterampilan sesuai dengan nilai-nilai pengajaran dalam islam. ${ }^{20}$ (Abnisa, 2017)

Berdasarkan tafsir ayat Al Qur'an yang membahas tentang pendidik dan peserta didik, dipandang dari sisi manajemen pendidikan bahwa pendidik dan peserta diidk merupakan Sumber Daya Manusia (SDM) yang keduanya dapat menjadi objek dan subjek pendidikan. Perencanaan SDM sangat diperlukan dalam setiap lembaga atau organisasi. Termasuk dalam lembaga pendidikan. Pendidik dan peserta didik sebagai SDM di sekolah memerlukan proses perencanaan agar dapat mencapai tujuan pendiidkan yang diharapkan. Perencanaan dilakukan mulai dari perekrutan, seleksi, pemetaan, penempatan dan pembagian tugas sesuai dengan posisi yang seharusnya. Dimana keduanya dapat menjadi sasaran dan juga pelaku kegiatan pendidikan. Untuk menjadikan pendidik dan peserta didik yang ideal maka diperlukan

Perencanaan SDM harus terkait dengan perencanaan organisasi secara keseluruhan karena tujuan perencanaan SDM harus menempatkan figur yang tepat waktu dan tepat tempat. Semuanya perlu direncanakan dengan matang. Bagaimanapun juga pendidik dan peserta didik merupakan SDM yang tidak akan ada artinya apabila salah satunya tidak ada. Perencanaan pendidik telah

${ }^{19}$ Alfiah, Hadist Tarbawi: Pendidikan Islam Dalam Tinjauan Hadist Nabi, Pekanbaru: Kreasi Edukasi, 2015.

20 Almaydza Pratama Abnisa, Konsep Pendidik Dan Peserta Didik Dalam Perspektif Al-Qur'an, Jurnal Asy- Syukriyyah (2017). 
diatur sedemikian rupa oleh pemerintah maupun lembaga pendidikan. Mulai dari analiis kebutuhan pendidik, seleksi. Perencanaan terhadap peserta didik menyangkut perencanaan penerimaan siswa baru, kelulusan, jumlah putus sekolah dan kepindahan.

Pendidik utama dalam Al Quran adalah Allah SWT, Rasulullah SAW, orang tua yaitu ayah dan ibu, guru dan alam. Idealnya pendidik meneladani apa yang telah dijelaskan dalam Al Quran seperti yang telah dijabarkan uraian materi tentang pendidik dan peserta didik diatas. Pendidik yang ideal dalam perspektif Al Quran memiliki ciri sebagai berikut,

1. Jujur. Nabi shallallahu 'alaihi wa sallam bersabda (yang artinya), "Hendaklah kalian jujur, karena kejujuran akan menghantarkan kepada kebaikan dan kebaikan akan menghantarkan ke surga" (H.R. Bukhori dan Muslim dari Ibnu Mas'ud ra). Jujur merupakan sikap mulia yang harus ditumbuhkan dalam kepribadian guru dan peserta didik. Setiap guru dan peserta didik hendaknya lurus hatti, tidak membiasakan berbohong, dan menyampaikan yang sebenar-benarnya. Sehingga tidak ada pihak yang merasa didustai.

2. Sabar. Guru sebagai pendidik tidak boleh bosan dan jenuh dalam membimbing, membina dan mendidik peserta didik untuk mau belajar dan sselalu berbuat baik.

3. Arif bijaksana. Guru adalah sosok yang yang menjadi panutan bagi peserta didik. Harus berlaku adil dan tidak boleh memihak pada siapapun dengan tidak adil

4. Berkepribadian mantap. Memiliki kepribadian yang sesuai dengan karakteristik pendidik, beraklhlakul kharimah dan agamis.

5. Dewasa. Akil baligh (dewasa), memiliki kematangan berfikir dan bersikap maupun bertindak.

6. Menjadi tauladan. Guru adalah sosok yang digugu dan ditiru, harus dapat menjadi tauladan bagi peserta didknya. Menerapkan slogan tut wuru handayani. Sebagai pendidik di depan menjadi teladan, ditengah memberi ide dan dibelakang memberi dorongan.

Guru merupakan pewaris yang menerima risallah untuk meneruskan pembelajaran kepada sertiap peserta didik. Beberapa nasehat islami yang diberikan pada guru yaitu,

1. guru hendaknya percaya diri dan waspada dengan tugasnya karena guru merupakan peawris nabi sebagai pendidik. Adapun dalil mengenai nasihat ini dari Al-Qur'an, Allah berfirman, “...niscaya Allah akan meninggikan orang-oramg beriman diantara kamu dan orang-orag yang diberi ilmu pengetahuan beberapa derajat. Dan allah mengetahui apa yang kamu kerjakan." (al-mujaadalah : 11). Rasulullah noticed juga menjelaskan kekdudukan ulama di mata Allah dalam sabda, " Keutamaan orang alim itu di atas orang ahli ibadah seperti bulan di antara bintang- 
bintang, sesungguhnya para ulama itu adalah pewaris nabi....."

2. selalu memperbaiki hubungan dengan siapapun termasuk pihak sekolah. Karena memperbaiki akhlak adalah bagian dari iman.

3. mempersiapkan diri sebagai sosok yang akan diteladani dan jadi panutan baik dari segi penampilan, perkataan dan perbuatan. Berpakaian sebagai guru, berkata sebagai guru dan berbuat sebagai guru. Allah telah berfirman, “ Dan hendaklah ada di antara kamu segolongn umat yang menyeru kepada kebajika, mmenyuruh kepada yang makruf dan mencegah dari yang mungkar, merekalah orang-orang beruntung

4. berpenampilan rapi dan bersih serta bertutur kata sopan dan santun rasulullah bersabda, " Tidak akan masuk surge orang yang di dalam hatinya terdapat sebiji zahrah rasa kesombongan, kemudian seseoranng bertanya, "Wahai Rasulullah, bagaimana dengan seseorang yang merasa bila baju dan sadly kakinya bagus ?" Rasulullah bersabda, Sesungguhnya Allah itu indah dan suka keindahan."(HR. Musim)

5. menekuni profesi dengan tanggung jawab, cinta profesi, disiplin karena Allah mencintai orang yang mebgerjakan dengan sempurna.

6. memperlakukan peserta didik dengan lemah lembut dan penuh kasih sayang serta menyampaikan segala kebaikan

7. menjadi pemimpin yang welas asih, penuh kasih sayang, lemah lembut kepada semua peserta didik. Dalam firman Allah, SWT, " Sesungguhnya telah ada pada (diri) Rasulullah teladan yang baik bagimu (yaitu) bagi orang yang mengharap rahmat Allah dan (kedatangan) hari kiamat dan dia banyak menyebut Allah" (Al-Ahzab: 21)

8. membiasakan diri aktif pada kegiatan sekolah dengan tulus iklas. Rasulullah bersabda, " Allah mencintai seseorang yang apabila ia mengerjakan suatu pekerjaan, maka ia mengerjakannya dengan sempurna".

9. menyampaikan dakwah kepada peserta didik tentang iman dan islam

10. berlaku seimbang. Dalil dari nasehat ini dari Al-Quran adalah firman Allah yang berbunyi, "Dan demikian (pula) kami telah menjadikan kamu(umat islam), umat yang adil dan pilihan agar kamu menjadi saksi atas (perbuatan) manusia dan agar Rasul (Muhammad) menjadi saksi atas perbuatan kamu..."

Beberapa pendapat tentang bahwa proses belajar-mengajar itu tidak ada kaitannya dengan kesalehan, keteladan dan akhlak. Pendapat ini berkeyakinan bahwasanya proses belajar-mengajar tersebut murni berlandaskan atas sebab usaha belaka, yakni barangsiapa yang baik dalam usahanya maka ia berprestasi dan barang siapa yang lalai dan buruk usahanya, maka ia akan terbelakang dan gagal. Semuanya ini adalah metode pemikiran sekuler. Tapi di antara orang-orang, ada juga yang berpendapat bahwa kesalehanitu berperan sekali sebagai memotivasi dan pembantu 
utama dalam usah yang baik menuju suatu prestasi, karena tidak mungkin memisahkan antara agama dan dunia ilmu serta dunia belajar, ini adalah metode pemikiran islam komprehensif.

Kesalehan yang efektif dalam islam adlah yang mampu mempengaruhi perilaku dan perbuatan seseorang muslim agar sesuai dengan syariat islam, sehingga manusia bisa merasakan hidup mulia dan bahagia dengan ridho Allah di akhirat. Pengaruh dari kesalehan yang efektif bagi seorang guru tercermin pada perilaku dan perbuatannya, khususnya dalam kesehariannya ketika bersama para pelajar, maka guru itu akan member contoh mereka dengan akhlak dan perbuatannya. Contoh dasar kesalehan yang efektif bagi seorang guru serta pengaruhnya bagi para penuntut ilmu, diantarany sebagai berikut :

1. Selalu mengucap salam ketika masuk kedalam ruangan

2. Mengawali setiap kegiatan dengan doal

3. Menggunakan waktu dengan efektif dan efisien

4. Guru hendaknya dapat menanamkan pemahaman kepada peserta didik tentang pengalaman belajar, karakter yang kuat dibarengi keahlian dan kepiawaian dalam mengajar

5. Guru menghargai setiap karakter peserta didik dan mendidik dengan tulus, ikhlas, sabar, welas asih dan pemaaf

6. Menyampaikan materi dengan cara sederhana dan mudah dipamahi oleh peserta ddiik

7. Bersikap lemah lembut dan sabar dalam menghadapi peserta didik dengan kategori itimewa

8. Tidak kaku dalam menyampaikan materi pelajaran. Guru harus bisa menyelingi dengan suasana humor dalam kegiatan belajar agar peserta didik tidak merasa tegang

9. Memahami perbedaan kultur dan latar belakang peserta didik

10. Guru hendaknya segera membantu mencarikan solusi dari permasalahan yang dialami oleh peserta didik

11. Menggunakan berbagai cara untuk memotivasi peserta didik

12. Berpegang teguh pada syariat agama islam

13. Kesalehan pendidik yang efektif adalah motif menuju prestasi ilmiah untuk peserta didik. Hal tersebut merupakan tuntunan syariat dan kebutuhan manusia. Kesalehan efektif kakn mewujudkan kepada peserta didik bebrapa manfaat yang dapat membantu untuk berprestasi. 


\section{Kesimpulan}

Pendidik dan Lembaga pendidikan merupakan sistem yang harus dikembangkan sesuai dengan syariat. Keduanya memeiliki peran saling ketergantungan satu sama lain. Pendidik tidak dapat menjalankan semua tugas dan tanggung jawab tidak ada peserta didik sebagai sumber daya manusia yang menerima pendidikan. Sebaliknya juga Lembaga Pendidikan merupakan wadah dalam menjalankan sistem dan proses pembelajaran kepada peserta didik.

Pendidik merupakan siapa saja yang berperan memberikan pembelajaran, bukan hanya manusia dewasa semata. Allah SWT merupakan pendidik utama, begitu juga Rasulullah SAW merupakan pendidik umat di dunia. Selanjutnya orang tua yaitu ayah dan ibu selaku pendidik yang pertama dikenal setelah manusia lahir ke dunia dan berada pada lingkungan pertama yaitu keluarga. Guru sebagai pendidik yang berada di lingkungan sekolah merupakan orang yang lebih dikenal masyarakat sebagai pendidik. Tidak hanya itu saja, lingkungan alam juga dapat menjadi sumber belajar atau pendidik bagi siapapun.

Pendidik dalam artian sosok yang digugu dan ditiru memiliki peran yang sangat besar dalam membentuk akhlakul karimah peserta didik menjadi generasi yang salih. Orang tua selaku pendidik pertama yang dikenal anak dalam lingkungan keluarga, guru sebagai pendidik di sekolah perlu menjadi sosok yang patut ditauladani selain rasulullah SAW untuk menjadikan generasi salih. Pendidik memiliki peran dalam membentuk kesalehan peserta didik. pendidikan memeiliki peran penting dalam membentuk kesalehan peserta didik. Melalui proses pendidikan dan pengajaran nilai-nilai kesalehan ditanamkan kepada peserta didik.

\section{Daftar Pustaka}

Abnisa, Almaydza Pratama, Konsep Pendidik Dan Peserta Didik Dalam Perspektif Al-Qur'an, Jurnal Asy- Syukriyyah (2017).

Alfiah, Hadist Tarbawi: Pendidikan Islam Dalam Tinjauan Hadist Nabi, Pekanbaru: Kreasi Edukasi, 2015.

Anas, Nazifah, Rasulullah Sebagai Pendidik Professional, 2015.

Arikunto Suharsimi, Prosedur Penelitian Suatu Pendekatan Praktik, 2006.

Arsyad, Junaidi, Karakteristik Rasulullah sebagai Pendidik, Perspektif Sirah Nabawiyah, 2015.

Asmendri, Milya Sari dan, Penelitian Kepustakaan (Library Research), Penelitian Pendidikan IPA, (2020).

Maisyaroh, Hakikat Pendidik dalam Perspektif Falsafah Pendidikan Islami, 2019. Maragustam, Filsafat Pendidikan Islam. Yogyakarta: Sunan Kalijaga, 2010. M. Yusuf Seknun, Kedudukan Guru Sebagai Pendidik, 2012. 
Nata, Abuddin, Filsafat Pendidikan Islam, Jakarta: Logos Wacana Ilmu, 1997.

Nizar, Ramayulis dan Syamsul, Filsafat Pendidikan Islam: Telaah Sistem Pendidikan dan Pemikiran Para Tokohnya, Jakarta: Kalam Mulia, 2010.

Sada, Heru Juabdin, Pendidik dalam Perspektif Al Quran, 2015.

Poerwadarminta, W.J.S., Kamus Umum Bahasa Indonesia, Jakarta: Balai Pustaka, 1991.

Suarga, Tugas dan Fungsi Manajemen Pendidik dan Tenaga Kependidikan, Jurnal Idaarah 3, no 1 (2019).

Siahaan, Amiruddin dan Nur Hidayah, 2014, Hadis-Hadis tentang Peserta Didik, Nadwa, Jurnal Pendidikan Islam 8, no 1, (2014).

Tafsir, Ahmad, Ilmu Pendidikan dalam Perspektif Islam, Bandung: Remaja Rosdakarya, 2002.

Undang-Undang RI No. 20 Tahun 2003, Tentang Sistem Pendidikan Nasional, Jakarta: Departemen Pendidikan Nasional, 2003.

Wahidin, Ade, Filosofi Manusia Sebagai Pendidik, 2015.

Yuniedel, Ratna Kasni dan sasmi Nelwati, meneladani Rasulullah SAW Sebagai Pendidik Yang Menmudahkan. 